Article

\title{
New 1,4-Dienonesteroids from the Octocoral Dendronephthya sp.
}

\author{
Thanh-Hao Huynh ${ }^{1,2, \dagger}{ }^{\text {, Pei-Chin Chen }}{ }^{3,+}$, San-Nan Yang ${ }^{4}$, Feng-Yu Lin ${ }^{2,5}$, Tung-Pin Su ${ }^{1,2}$, \\ Lo-Yun Chen ${ }^{2,6}$, Bo-Rong Peng ${ }^{2,3,7}$, Chiung-Chin $\mathrm{Hu}^{2}{ }^{2}$, You-Ying Chen ${ }^{2,8}$, Zhi-Hong Wen ${ }^{8}$ (D), \\ Tung-Ying $\mathrm{Wu}^{9, *}$ and Ping-Jyun Sung $1,2,8,9,10, * \mathbb{C}$ \\ 1 Graduate Institute of Marine Biology, National Dong Hwa University, Pingtung 944, Taiwan \\ 2 National Museum of Marine Biology and Aquarium, Pingtung 944, Taiwan \\ 3 Doctoral Degree Program in Marine Biotechnology, National Sun Yat-sen University, Kaohsiung 804, Taiwan \\ 4 Department of Pediatrics, E-DA Hospital, School of Medicine, College of Medicine, I-SHOU University, \\ Kaohsiung 804, Taiwan \\ 5 Department of Applied Chemistry, National Pingtung University, Pingtung 900, Taiwan \\ 6 Department of Chemistry, National Sun Yat-sen University, Kaohsiung 804, Taiwan \\ 7 Doctoral Degree Program in Marine Biotechnology, Academia Sinica, Taipei 115, Taiwan \\ 8 Department of Marine Biotechnology and Resources, National Sun Yat-sen University, \\ Kaohsiung 804, Taiwan \\ 9 Chinese Medicine Research and Development Center, China Medical University Hospital, \\ Taichung 404, Taiwan \\ 10 Graduate Institute of Natural Products, Kaohsiung Medical University, Kaohsiung 807, Taiwan \\ * Correspondence: kuma0401@gmail.com (T.-Y.W.); pjsung@nmmba.gov.tw (P.-J.S.); Tel.: +886-4-2205-3366 \\ (ext. 5163) (T.-Y.W.); +886-8-882-5037 (P.-J.S.); Fax: +886-8-882-5087 (P.-J.S.) \\ + These authors contributed equally to this work.
}

Received: 6 August 2019; Accepted: 10 September 2019; Published: 11 September 2019

\begin{abstract}
Two new steroids, dendronesterones D (1) and E (2), featuring with 1,4-dienone moiety, along with three known steroids, methyl 3-oxochola-4,22-diene-24-oate (3), $5 \alpha, 8 \alpha$-epidioxy-24(S)methylcholesta-6,22-dien-3 $\beta$-ol (4), and $5 \alpha, 8 \alpha$-epidioxy-24(S)-methylcholesta-6,9(11),22-trien-3 $\beta$-ol (5), were isolated from an octocoral Dendronephthya sp. The structures of steroids $\mathbf{1}$ and $\mathbf{2}$ were elucidated by using spectroscopic methods and steroid 1 was found to exhibit significant in vitro anti-inflammatory activity in lipopolysaccharides (LPS)-induced RAW264.7 macrophage cells by inhibiting the expression of the iNOS protein.
\end{abstract}

Keywords: Dendronephthya; dendronesterone; steroid; anti-inflammatory; iNOS

\section{Introduction}

Marine invertebrates, particularly octocorals have been well recognized as a rich source of interesting steroid metabolites [1]. In continuation of research into new substances from marine invertebrates collected off the waters of Taiwan, a series of steroid derivatives have been isolated from the octocorals belonging to the genus Dendronephthya (phylum Cnidaria, class Anthozoa, order Alcyonacea, family Nephtheidae), octocorals distributed in the tropical and subtropical waters of the Indo-Pacific Ocean, and some of these metabolites were found to possess interesting bioactivities, such as cytotoxic [2] and anti-inflammatory activity [3,4]. Recently, chemical examination of an octocoral identified as Dendronephthya sp. resulted in the isolation of two new marine steroids, dendronesterones D (1) and E (2) (Figure 1), along with three known steroids, including an antifouling compound, methyl 3-oxochola-4,22-dien-24-oate (3), which was first isolated from a Japanese soft coral Dendronephthya sp. [5], and two cytotoxic metabolites, $5 \alpha, 8 \alpha$-epidioxy-24(S)-methylcholesta-6,22-dien-3 $\beta$-ol (4) and 
$5 \alpha, 8 \alpha$-epidioxy-24(S)-methylcholesta- 6,9(11),22-trien-3 $\beta$-ol (5) [6] (Figure 1), which were obtained from various marine invertebrates, such as sea squirts Trididemnum inarmatum [6] and Ascidia nigra [7], a hard coral Dendrogyra cylindrus [7], and a sponge Thalysias juniperina [7]. We reported herein the isolation and structural determination of steroids 1-5. The ability of $\mathbf{1 - 5}$ to reduce the expression of the pro-inflammatory iNOS (inducible nitric oxide synthase) and COX-2 (cyclooxygenase-2) proteins in LPS (lipopolysaccharides)-stimulated RAW264.7 macrophage cells was determined.

(A)

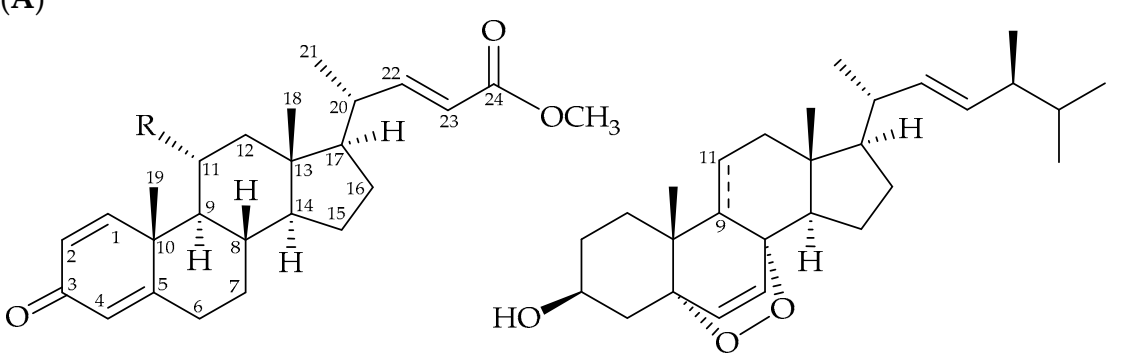

1: $\mathrm{R}=\mathrm{OAc}, 2: \mathrm{R}=\mathrm{OH}, 3: \mathrm{R}=\mathrm{H}$

4: 9,11-saturated, 5: $\Delta^{9(11)}$

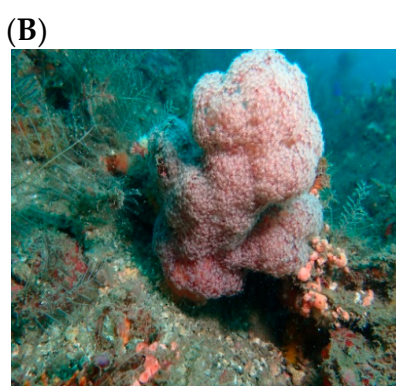

Dendronephthya sp.

Figure 1. (A) Structures of dendronesterones D (1), E (2), methyl 3-oxochola-4,22-dien-24-oate (3), $5 \alpha, 8 \alpha$-epidioxy-24(S)-methylcholesta-6,22-dien-3 $\beta$-ol (4), $5 \alpha, 8 \alpha$-epidioxy-24(S)-methylcholesta-6,9

(11),22-trien-3 $\beta$-ol (5), and (B) A picture of octocoral Dendronephthya sp.

\section{Results}

The new metabolite dendronesterone D (1) was isolated as a colorless oil, and its molecular formula was established as $\mathrm{C}_{27} \mathrm{H}_{36} \mathrm{O}_{5}$ (unsaturation degrees = 10) from a sodium adduct at $m / z 463$ in the (+)-ESIMS and further supported by the (+)-HRESIMS at $m / z 463.24530$ (calculated for $\mathrm{C}_{27} \mathrm{H}_{36} \mathrm{O}_{5}$ $+\mathrm{Na}, 463.24550)$. The ${ }^{13} \mathrm{C}$ and DEPT spectroscopic data showed that this compound has 27 carbons (Table 1), including five methyls, five $\mathrm{sp}^{3}$ methylenes, $\mathrm{six} \mathrm{sp}^{3}$ methines, two $\mathrm{sp}^{3}$ quaternary carbons, five $\mathrm{sp}^{2}$ methines, an $\mathrm{sp}^{2}$ quaternary carbon, two ester carbonyls, and a ketonic carbonyl. The IR spectrum revealed the presence of ester carbonyl $\left(1724 \mathrm{~cm}^{-1}\right)$ and $\alpha, \beta$-unsaturated ketonic $\left(1663 \mathrm{~cm}^{-1}\right)$ groups. The ${ }^{1} \mathrm{H}$ NMR spectra (Table 1$)$ showed the presence of five olefinic methine protons $\left(\delta_{\mathrm{H}} 6.78, \mathrm{~d}\right.$, $J=10.8 \mathrm{~Hz} ; 6.74, \mathrm{dd}, J=15.6,10.0 \mathrm{~Hz} ; 6.13, \mathrm{dd}, J=10.8,2.0 \mathrm{~Hz} ; 6.10, \mathrm{dd}, J=2.0,1.6 \mathrm{~Hz} ; 5.79, \mathrm{~d}, J=15.6$ $\mathrm{Hz})$ and an oxymethine proton $\left(\delta_{\mathrm{H}} 5.17, \mathrm{ddd}, J=10.8,10.8,5.6 \mathrm{~Hz}\right)$. In addition, a carbonyl resonance at $\delta_{\mathrm{C}} 169.7$ further confirmed the existence of an ester group. The result of ${ }^{1} \mathrm{H}$ NMR spectrum analysis indicated an acetate methyl $\left(\delta_{\mathrm{H}} 2.01,3 \mathrm{H}, \mathrm{s}\right)$. The carbon signals at $\delta_{\mathrm{C}} 156.2(\mathrm{CH}), 125.7(\mathrm{CH}), 186.2(\mathrm{C})$, $124.6(\mathrm{CH})$, and $167.1(\mathrm{C})$ as well as the proton at $\delta_{\mathrm{H}} 6.78(1 \mathrm{H}, \mathrm{d}, J=10.8 \mathrm{~Hz}), 6.13(1 \mathrm{H}, \mathrm{dd}, J=10.8$, $2.0 \mathrm{~Hz})$, and $6.10(1 \mathrm{H}, \mathrm{dd}, J=2.0,1.6 \mathrm{~Hz})$ were characteristic signals of steroids with a 1,4-dien-3-one moiety in ring A [8-12]. 
Table 1. ${ }^{1} \mathrm{H}\left(400 \mathrm{MHz}, \mathrm{CDCl}_{3}\right)$ and ${ }^{13} \mathrm{C}\left(100 \mathrm{MHz}, \mathrm{CDCl}_{3}\right) \mathrm{NMR}$ data for steroids $\mathbf{1}$ and 2.

\begin{tabular}{|c|c|c|c|c|}
\hline \multirow[b]{2}{*}{$\mathbf{C} / \mathbf{H}$} & \multicolumn{2}{|l|}{1} & \multicolumn{2}{|l|}{2} \\
\hline & $\delta_{\mathrm{H}}(J$ in $\mathrm{Hz})$ & $\delta_{C}$, Type & $\delta_{\mathrm{H}}(J$ in $\mathrm{Hz})$ & $\delta_{C}$, Type \\
\hline 1 & $6.78 \mathrm{~d}(10.8)$ & $156.2(\mathrm{CH})$ & $7.74 \mathrm{~d}(10.8)$ & $158.8(\mathrm{CH})$ \\
\hline 2 & $6.13 \mathrm{dd}(10.8,2.0)$ & $125.7(\mathrm{CH})$ & $6.15 \mathrm{dd}(10.8,2.0)$ & $125.1(\mathrm{CH})$ \\
\hline 3 & & $186.2(\mathrm{C})$ & & $183.8(\mathrm{C})$ \\
\hline 4 & $6.10 \mathrm{dd}(2.0,1.6)$ & $124.6(\mathrm{CH})$ & $6.09 \mathrm{dd}(2.0,1.2)$ & $124.6(\mathrm{CH})$ \\
\hline 5 & & $167.1(\mathrm{C})$ & & $167.9(\mathrm{C})$ \\
\hline $6 \alpha$ & 2.38 ddd $(13.2,4.4,2.4)$ & $32.8\left(\mathrm{CH}_{2}\right)$ & 2.36 ddd $(13.2,4.4,2.8)$ & $33.2\left(\mathrm{CH}_{2}\right)$ \\
\hline$\beta$ & $\begin{array}{c}2.48 \text { ddd }(13.2,13.2,4.8, \\
0.8)\end{array}$ & & $\begin{array}{c}2.45 \text { ddd }(13.2,13.2,5.2 \\
1.6)\end{array}$ & \\
\hline $7 \alpha / \beta$ & $1.14 \mathrm{~m} ; 1.97 \mathrm{~m}$ & $33.3\left(\mathrm{CH}_{2}\right)$ & $1.09 \mathrm{~m} ; 1.96 \mathrm{~m}$ & $33.4\left(\mathrm{CH}_{2}\right)$ \\
\hline 8 & $1.72 \mathrm{~m}$ & $34.4(\mathrm{CH})$ & $1.61 \mathrm{~m}$ & $34.3(\mathrm{CH})$ \\
\hline 9 & $1.39 \mathrm{dd}(10.8,10.8)$ & $56.3(\mathrm{CH})$ & $1.09 \mathrm{dd}(10.4,10.4)$ & $60.2(\mathrm{CH})$ \\
\hline 10 & & $43.4(\mathrm{C})$ & & $44.0(\mathrm{C})$ \\
\hline 11 & $5.17 \mathrm{ddd}(10.8,10.8,5.6)$ & $69.8(\mathrm{CH})$ & $3.99 \mathrm{~m}$ & $67.9(\mathrm{CH})$ \\
\hline $12 \alpha / \beta$ & $\begin{array}{c}1.00 \mathrm{dd}(12.4,10.8) ; 2.13 \\
\mathrm{dd}(12.4,5.6)\end{array}$ & $44.7\left(\mathrm{CH}_{2}\right)$ & $1.00 \mathrm{~m} ; 2.10 \mathrm{dd}(12.0,4.8)$ & $50.0\left(\mathrm{CH}_{2}\right)$ \\
\hline 13 & & $42.5(\mathrm{C})$ & & $42.9(\mathrm{C})$ \\
\hline 14 & $1.14 \mathrm{~m}$ & $53.9(\mathrm{CH})$ & $1.09 \mathrm{~m}$ & $54.5(\mathrm{CH})$ \\
\hline $15 \alpha / \beta$ & $1.67 \mathrm{~m} ; 1.16 \mathrm{~m}$ & $23.9\left(\mathrm{CH}_{2}\right)$ & $1.63 \mathrm{~m} ; 1.18 \mathrm{~m}$ & $24.0\left(\mathrm{CH}_{2}\right)$ \\
\hline $16 \alpha / \beta$ & 1.92 m; 1.36 m & $27.4\left(\mathrm{CH}_{2}\right)$ & $1.93 \mathrm{~m} ; 1.38 \mathrm{~m}$ & $27.7\left(\mathrm{CH}_{2}\right)$ \\
\hline 17 & $1.30 \mathrm{dd}(9.2,9.2)$ & $55.3(\mathrm{CH})$ & $1.32 \mathrm{~m}$ & $55.3(\mathrm{CH})$ \\
\hline 18 & $0.76 \mathrm{~s}$ & $12.9\left(\mathrm{CH}_{3}\right)$ & $0.73 \mathrm{~s}$ & $13.3\left(\mathrm{CH}_{3}\right)$ \\
\hline 19 & $1.26 \mathrm{~s}$ & $18.7\left(\mathrm{CH}_{3}\right)$ & $1.25 \mathrm{~s}$ & $18.7\left(\mathrm{CH}_{3}\right)$ \\
\hline 20 & $2.24 \mathrm{~m}$ & $39.5(\mathrm{CH})$ & $2.25 \mathrm{~m}$ & $40.0(\mathrm{CH})$ \\
\hline 21 & $0.97 \mathrm{~d}(6.4)$ & $19.8\left(\mathrm{CH}_{3}\right)$ & $0.99 \mathrm{~d}(6.4)$ & $20.0\left(\mathrm{CH}_{3}\right)$ \\
\hline 22 & $6.74 \mathrm{dd}(15.6,10.0)$ & $154.0(\mathrm{CH})$ & $6.84 \mathrm{dd}(15.6,10.4)$ & $154.8(\mathrm{CH})$ \\
\hline 23 & $5.79 \mathrm{~d}(15.6)$ & $119.3(\mathrm{CH})$ & $5.81 \mathrm{~d}(15.6)$ & $119.2(\mathrm{CH})$ \\
\hline 24 & & $166.8(\mathrm{C})$ & & $167.2(\mathrm{C})$ \\
\hline OAc-11 & & 169.7 (C) & & \\
\hline & $2.01 \mathrm{~s}$ & $21.6\left(\mathrm{CH}_{3}\right)$ & & \\
\hline OMe-24 & $3.72 \mathrm{~s}$ & $51.3\left(\mathrm{CH}_{3}\right)$ & $3.74 \mathrm{~s}$ & $51.5\left(\mathrm{CH}_{3}\right)$ \\
\hline
\end{tabular}

${ }^{1} \mathrm{H}$ NMR coupling information in the COSY spectrum of $\mathbf{1}$ enabled identification of $\mathrm{H}-1 / \mathrm{H}-2$, $\mathrm{H}-2 / \mathrm{H}-4$ (by a long range $W$-coupling), $\mathrm{H}_{2}-6 / \mathrm{H}_{2}-7 / \mathrm{H}-8 / \mathrm{H}-9 / \mathrm{H}-11 / \mathrm{H}_{2}-12, \mathrm{H}-8 / \mathrm{H}-14 / \mathrm{H}_{2}-15 / \mathrm{H}_{2}-16 / \mathrm{H}-17 /$ $\mathrm{H}-20 / \mathrm{H}-22 / \mathrm{H}-23$, and $\mathrm{H}-20 / \mathrm{H}_{3}-21$ (Figure 2). These data, together with the key heteronuclear multiple bond correlation (HMBC) between protons and quaternary carbons, such as $\mathrm{H}-1 / \mathrm{C}-3 ; \mathrm{H}-1, \mathrm{H}_{2}-6$, $\mathrm{H}_{3}-19 / \mathrm{C}-5$; H-1, H-4, H-9, H-11, $\mathrm{H}_{3}-19 / \mathrm{C}-10 ; \mathrm{H}_{2}-12, \mathrm{H}_{3}-18 / \mathrm{C}-13$; and H-22, H-23/C-24, allowed us to establish the molecular skeleton of $\mathbf{1}$. H-11 $\left(\delta_{\mathrm{H}} 5.17\right)$ showed HMBC to C-10 and acetate carbonyl carbon at $\delta_{C} 169.7$, demonstrating the acetoxy group at $C-11$. The methoxy group at $C-24$ was confirmed by the HMBC between the methyl protons of methoxy group $\left(\delta_{H} 3.72\right)$ and $C-24\left(\delta_{C} 166.8\right)$.

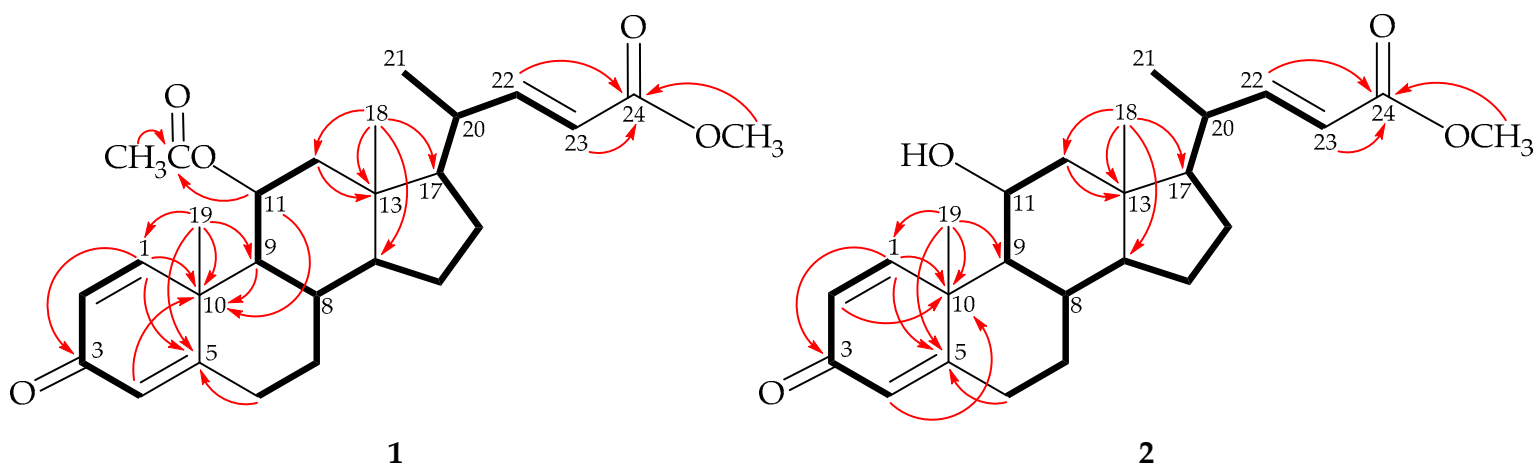

Figure 2. The COSY (-) correlations and selective $\operatorname{HMBC}(\curvearrowright)$ of steroids 1 and 2.

The relative configuration of $\mathbf{1}$ was elucidated by the NOE correlations observed in a NOESY experiment. $\mathrm{H}-8$ showed correlations with both $\mathrm{H}_{3}-18$ and $\mathrm{H}_{3}-19$, and $\mathrm{H}_{3}-18$ exhibited correlations with $\mathrm{H}-11$ and $\mathrm{H}-20$; therefore, due to the $\beta$-orientation of Me-18 at C-13, all of $\mathrm{H}-8, \mathrm{H}-11, \mathrm{H}_{3}-19$, and $\mathrm{H}-20$ should be positioned on the $\beta$-face. Furthermore, NOE responses between $\mathrm{H}-14$ and $\mathrm{H}-9$, and 
H-14 and H-17, were observed on the $\alpha$-orientation of H-9, H-14, and H-17 (Figure 3) (Supplementary Materials, Figures S1-S10).

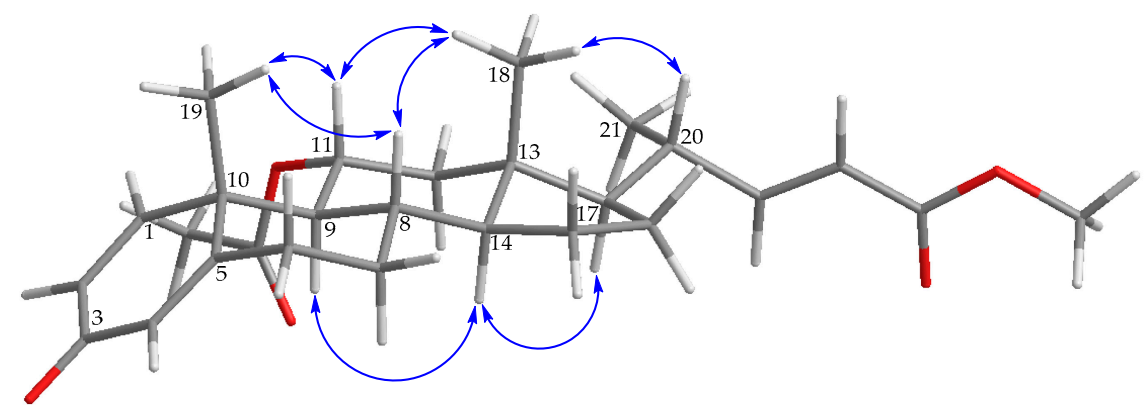

Figure 3. Selective protons with key NOESY correlations (ん) of $\mathbf{1}$.

Steroid 2 (dendronesterone $\mathrm{E}$ ) was isolated a colorless oil and was found to possess a molecular formula $\mathrm{C}_{25} \mathrm{H}_{34} \mathrm{O}_{4}$, as determined by (+)-HRESIMS at $m / z 421.23502$ (calculated for $\mathrm{C}_{25} \mathrm{H}_{34} \mathrm{O}_{4}+\mathrm{Na}$, 421.23493). IR absorptions at 3395, 1720, and $1657 \mathrm{~cm}^{-1}$ revealed the presence of hydroxy, ester, and $\alpha, \beta$-unsaturated ketonic groups. Comparison of the ${ }^{1} \mathrm{H}$ and ${ }^{13} \mathrm{C}$ NMR data of 2 with those of $\mathbf{1}$ (Table 1) suggested that $\mathbf{2}$ is the 11-O-deacetyl analogue of $\mathbf{1}$. This was further confirmed by the upfield shifts observed for H-11 $\left(\delta_{\mathrm{H}} 3.99\right)$ and $\mathrm{C}-11\left(\delta_{\mathrm{C}} 67.9\right)$ relative to those of $\mathbf{1}\left(\delta_{\mathrm{H}} 5.17 ; \delta_{\mathrm{C}} 69.8\right)$. The planar structure of 2 , including the positions of hydroxy group, carboxylate, and the olefinic double bonds, could be deduced from analysis of 2D NMR spectrum, including COSY and HMBC (Figure 2). The relative stereochemistry of $\mathbf{2}$ was established by the analysis of the NOE correlations in NOESY spectrum of $\mathbf{2}$, as illustrated in Figure 4 (Supplementary Materials, Figures S11-S20).

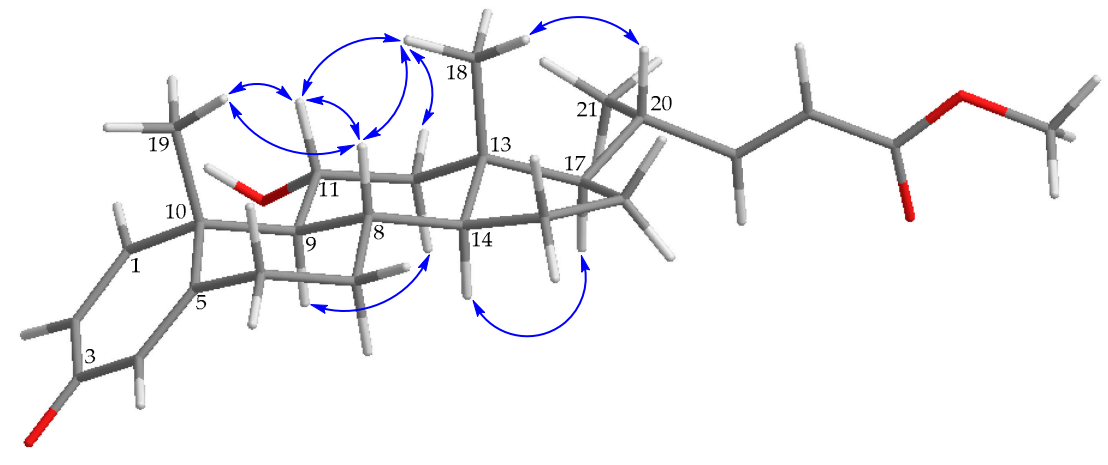

Figure 4. Selective protons with key NOESY correlations $(\curvearrowleft)$ of 2.

The known steroids 3-5 were identified as methyl 3-oxochola-4,22-dien-24-oate [5], 5 $5,8 \alpha-$ epidioxy-24(S)-methylcholesta-6,22-dien-3 $\beta$-ol [6,7], and 5 $\alpha, 8 \alpha$-epidioxy-24(S)-methylcholesta-6,9 (11),22-trien-3 $\beta$-ol $[6,7]$, respectively, according to a comparison of their spectroscopic data analysis with the information described in the literature.

Using an in vitro pro-inflammatory suppression assay, the effects of steroids 1-5 on the release of iNOS and COX-2 protein from LPS-stimulated RAW264.7 macrophage cells were assessed. The results of the in vitro pro-inflammatory suppression assay showed that steroid $\mathbf{1}$ at $10 \mu \mathrm{M}$ suppressed the expression of iNOS/ $\beta$-actin and COX-2/ $\beta$-actin to $24.2 \pm 10.6$ and $70.4 \pm 11.9 \%$, as compared with LPS alone group (Figure 5). Compounds $\mathbf{1} \mathbf{- 5}$ did not significantly affect the viability of macrophage cells 16 $\mathrm{h}$ after treatments. 
(A)

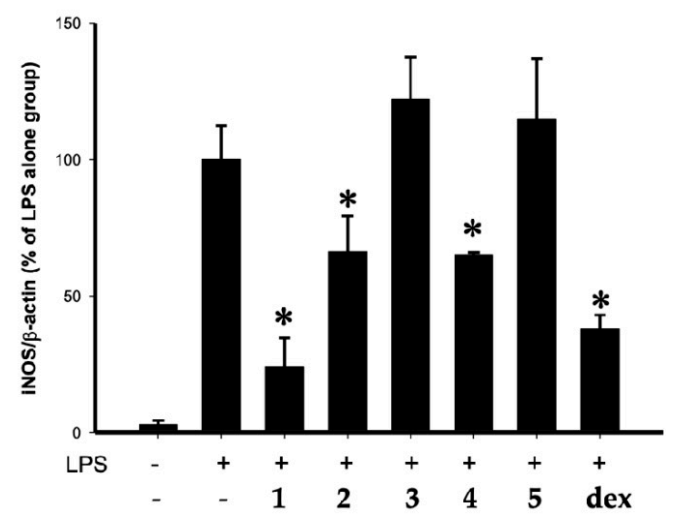

(B)

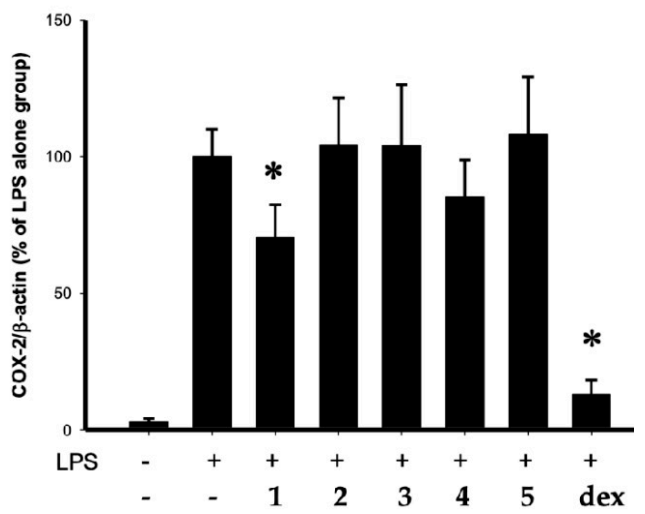

Figure 5. Effect of steroids 1-5 (10 $\mu \mathrm{M})$ on pro-inflammatory (A) iNOS and (B) COX-2 protein expressions in the lipopolysaccharides (LPS)-stimulated murine macrophage cell line RAW264.7 by Western blotting analysis (Supplementary Materials, Figure S21). The relative intensity of iNOS/ COX-2 to $\beta$-actin bands was normalized to LPS-stimulated group, and cells treated with dexamethasone were used as a positive control. ( ${ }^{*} p<0.05$, significantly different from the LPS-stimulated group). Data are expressed as the mean $\pm \operatorname{SEM}(n=3$ or 4$)$.

\section{Discussion}

Dendronephthya spp. have been demonstrated to have a wide structural diversity of interesting steroids that possess various pharmacological properties, specifically in anti-inflammatory activities $[13,14]$. In our study of Dendronephthya sp., two previously unreported steroids, dendronesterones D (1) and E (2), were isolated together with the previously described marine steroids, methyl

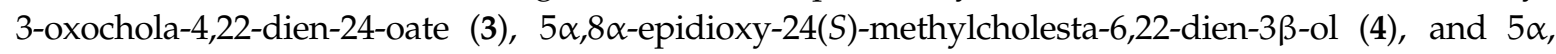
$8 \alpha$-epidioxy-24(S)-methylcholesta-6,9(11),22-trien-3 $\beta$-ol (5). In the present study, the structures of new metabolites 1 and 2 were elucidated by spectroscopic methods and anti-inflammatory activities of steroids 1-5 were assessed using inhibition of pro-inflammatory iNOS and COX-2 release from macrophages. The results indicated that dendronesterone $\mathrm{D}(\mathbf{1})$ showed the most potent suppressive effects on iNOS release and steroids 2 and $\mathbf{3}$ showed more weak suppressive effects on iNOS $/ \beta$-actin and COX-2/ $\beta$-actin expression than those of $\mathbf{1}$. The results suggested that the anti- inflammatory activities of steroids 1-3 were mainly reliant on the functional group at C-11. Furthermore, steroid $\mathbf{5}$ was found to be inactive in terms of reducing the expression of iNOS/ $\beta$-actin, indicating that the anti-inflammatory activities of steroids 4 and 5 are dependent on the existence of the carbon-carbon double bond between C-9/11.

\section{Experimental Section}

\subsection{General Experimental Procedures}

Optical rotations were measured on a Jasco P-1010 digital polarimeter (Japan Spectroscopic Corporation, Tokyo, Japan); infrared spectra were recorded on a Thermo, Nicolet iS5 FT-IR (Thermo Scientific Nicolet, Waltham, MA, USA); peaks are reported in $\mathrm{cm}^{-1}$. The NMR spectra were recorded on a Jeol FT-NMR (model ECZ400S, Tokyo, Japan) spectrometer operating at $400 \mathrm{MHz}$ for ${ }^{1} \mathrm{H}$ and 100 $\mathrm{MHz}$ for ${ }^{13} \mathrm{C}$, using the residual $\mathrm{CHCl}_{3}$ signal $\left(\delta_{\mathrm{H}} 7.26 \mathrm{ppm}\right)$ as an internal standard for ${ }^{1} \mathrm{H} \mathrm{NMR}$ and $\mathrm{CDCl}_{3}\left(\delta_{\mathrm{C}} 77.1 \mathrm{ppm}\right)$ for ${ }^{13} \mathrm{C}$ NMR; coupling constants $(J)$ are given in Hz. ESIMS and HRESIMS were recorded using a Bruker 7 Tesla solariX FTMS system (Bremen, Germany). Column chromatography was performed on silica gel (230-400 mesh, Merck). TLC was carried out on precoated Kieselgel $60 \mathrm{~F}_{254}\left(0.25 \mathrm{~mm}\right.$, Merck); spots were visualized by spraying with $10 \% \mathrm{H}_{2} \mathrm{SO}_{4}$ solution followed by heating. Normal-phase HPLC (NP-HPLC) was performed using a system comprised of a Hitachi 5110 pump (Hitachi, Tokyo, Japan) and a Rheodyne 7725 injection port (Rheodyne, Rohnert Park, CA, USA). A normal-phase column (Luna, $5 \mu \mathrm{m}$, Silica (2) $100 \AA, 250 \times 10 \mathrm{~mm}$ ) was used for NP-HPLC. 
Reversed-phase HPLC (RP-HPLC) was performed using a system comprised of a Hitachi L-2130 pump, a Hitachi L-2455 photodiode array detector, and a Rheodyne 7725 injection port. A reverse phase column (Luna, $5 \mu \mathrm{m} \mathrm{C18}(2) 100 \AA$, $250 \times 21.2 \mathrm{~mm}$ ) was used for RP-HPLC.

\subsection{Animal Material}

Specimens of the octocoral Dendronephthya sp. were collected by hand using self-contained underwater breathing apparatus (SCUBA) diving off the northeast coast of Taiwan in August 30th, 2018, and stored in a $-20^{\circ} \mathrm{C}$ freezer until extraction. A voucher specimen (NMMBA-TW-SC-2018-018) was deposited in the National Museum of Marine Biology and Aquarium (NMMBA), Taiwan. This organism was identified by comparison with previous descriptions [15].

\subsection{Extraction and Separation}

Sliced bodies of Dendronephthya sp. (wet weight $748.7 \mathrm{~g}$; dry weight $186.8 \mathrm{~g}$ ) were extracted with a 1:1 mixture of methanol $(\mathrm{MeOH})$ and dichloromethane to give $12.2 \mathrm{~g}$ of crude extract which was partitioned between ethyl acetate (EtOAc) and $\mathrm{H}_{2} \mathrm{O}$. The EtOAc extract $(2.4 \mathrm{~g})$ was applied on silica gel column chromatography and eluted with gradients of $n$-hexane/EtOAc (100:1-pure EtOAc, stepwise), to furnish 14 fractions (fractions: A-N). Fractions I, L, and M were purified by NP-HPLC using a mixture of $n$-hexane/acetone, $4: 1$ for fractions I and $\mathrm{M}$, and 6:1 for fraction $\mathrm{L}$, to afford 3 (8.5 $\mathrm{mg})$, $\mathbf{1}(6.6 \mathrm{mg})$, and $\mathbf{2}(3.0 \mathrm{mg})$, respectively. Fraction J was purified by NP-HPLC using a mixture of $n$-hexane/acetone (5:1) to yield nine fractions J1-J9. Fraction J6 was separated by RP-HPLC using a mixture of $\mathrm{MeOH} / \mathrm{H}_{2} \mathrm{O}(95: 5)$ to afford $5(0.6 \mathrm{mg})$ and $4(1.5 \mathrm{mg})$, respectively.

Dendronesterone D (1): Colorless oil: $[\alpha]_{\mathrm{D}}^{25}+79\left(\right.$ c $\left.0.3, \mathrm{CHCl}_{3}\right)$; IR (ATR) $v_{\max } 1724,1663 \mathrm{~cm}^{-1}$; ${ }^{1} \mathrm{H}\left(400 \mathrm{MHz}, \mathrm{CDCl}_{3}\right)$ and ${ }^{13} \mathrm{C}\left(100 \mathrm{MHz}, \mathrm{CDCl}_{3}\right) \mathrm{NMR}$ data, see Table 1; ESIMS $\mathrm{m} / z 463[\mathrm{M}+\mathrm{Na}]^{+}$; HRESIMS $m / z 463.24530$ (calculated for $\mathrm{C}_{27} \mathrm{H}_{36} \mathrm{O}_{5}+\mathrm{Na}, 463.24550$ ).

Dendronesterone E (2): Colorless oil: $[\alpha]_{\mathrm{D}}^{25}+57\left(c\right.$ 0.08, $\left.\mathrm{CHCl}_{3}\right)$; IR (ATR) $v_{\max } 3395,1720,1657$ $\mathrm{cm}^{-1} ;{ }^{1} \mathrm{H}\left(400 \mathrm{MHz}, \mathrm{CDCl}_{3}\right)$ and ${ }^{13} \mathrm{C}\left(100 \mathrm{MHz}, \mathrm{CDCl}_{3}\right)$ NMR data, see Table 1 ; ESIMS $\mathrm{m} / z$ 421 [M + $\mathrm{Na}^{+}$; HRESIMS $m / z 421.23502$ (calculated for $\mathrm{C}_{25} \mathrm{H}_{34} \mathrm{O}_{4}+\mathrm{Na}$, 421.23493).

Methyl 3-oxochola-4,22-dien-24-oate (3): Colorless oil: $[\alpha]_{\mathrm{D}}^{25}+52\left(c 0.2, \mathrm{CHCl}_{3}\right)\left(\right.$ ref. [5], $[\alpha]_{\mathrm{D}}^{22}+53.6(c$ $\left.\left.0.28, \mathrm{CHCl}_{3}\right)\right)$; IR (ATR) $v_{\max } 1721,1662 \mathrm{~cm}^{-1} ;{ }^{1} \mathrm{H}\left(400 \mathrm{MHz}, \mathrm{CDCl}_{3}\right)$ and ${ }^{13} \mathrm{C}\left(100 \mathrm{MHz}, \mathrm{CDCl}_{3}\right) \mathrm{NMR}$ data were found to be in full agreement with those reported previously [5]; ESIMS $\mathrm{m} / z 405[\mathrm{M}+\mathrm{Na}]^{+}$.

$5 \alpha, 8 \alpha$-Epidioxy-24(S)-methylcholesta-6,22-dien-3 $\beta$-ol (4): Amorphous powder: $[\alpha]_{\mathrm{D}}^{24}-6$ (c 0.07, $\left.\mathrm{CHCl}_{3}\right)$; IR (ATR) $v_{\max } 3375 \mathrm{~cm}^{-1} ;{ }^{1} \mathrm{H}\left(400 \mathrm{MHz}, \mathrm{CDCl}_{3}\right)$ and ${ }^{13} \mathrm{C}\left(100 \mathrm{MHz}, \mathrm{CDCl}_{3}\right)$ NMR data were found to be in full agreement with those reported previously [7]; ESIMS $m / z 451[\mathrm{M}+\mathrm{Na}]^{+}$.

$5 \alpha, 8 \alpha$-Epidioxy-24(S)-methylcholesta-6,9(11)22-trien-3 $\beta$-ol (5): Amorphous powder: $[\alpha]_{\mathrm{D}}^{24}+214(c$ $\left.0.2, \mathrm{CHCl}_{3}\right)$; IR (ATR) $v_{\max } 3391 \mathrm{~cm}^{-1} ;{ }^{1} \mathrm{H}\left(400 \mathrm{MHz}, \mathrm{CDCl}_{3}\right)$ and ${ }^{13} \mathrm{C}\left(100 \mathrm{MHz}, \mathrm{CDCl}_{3}\right) \mathrm{NMR}$ data were found to be in full agreement with those reported previously [7]; ESIMS $m / z 449$ [M+ Na] ${ }^{+}$.

\subsection{In Vitro Anti-Inflammatory Assay}

The anti-inflammatory activity method used was modified from our previous studies [16-18]. We examined the effects of steroids 1-5 on pro-inflammatory iNOS and COX-2 protein expressions in LPS-stimulated RAW264.7 cells by Western blotting analysis. RAW264.7 were obtained from the American Type Culture Collection (ATCC TIB-71, Mannassas, VA, USA). The cells was seeded in 10-cm dishes at a density of $1 \times 10^{6}$ cells. The inflammatory response was induced by incubation of LPS $(0.01 \mu \mathrm{g} / \mathrm{mL})$ for $16 \mathrm{~h}$. For the anti-inflammatory activity assay, steroids $\mathbf{1}-\mathbf{5}$ and dexamethasone (as positive control) at $10 \mu \mathrm{M}$ were added to the cells $10 \mathrm{~min}$ before LPS challenge. After $16 \mathrm{~h}$, the cells were then washed with ice-cold phosphate-buffered saline, lysed in lysis buffer (50 mM Tris, pH 7.5, $150 \mathrm{mM} \mathrm{NaCl}, 1 \%$ Triton X-100, $100 \mu \mathrm{g} / \mathrm{mL}$ phenylmethylsulfonyl fluoride and $1 \mu \mathrm{g} / \mathrm{mL}$ aprotinin), and centrifuged at 20,000 $\mathrm{g}$ for $30 \mathrm{~min}$ at $4{ }^{\circ} \mathrm{C}$. The supernatants were reserved for western blotting. Protein concentrations were measured by the DC protein assay kit (Bio-Rad, Hercules, CA, USA). An equal volume of sample buffer (2\% 2-mercaptoethanol, $2 \%$ sodium dodecyl suflate (SDS), $0.1 \%$ 
bromophenol blue, $10 \%$ glycerol, and $50 \mathrm{mM}$ Tris- $\mathrm{HCl}(\mathrm{pH} 7.2)$ ) was added to the samples, and the protein lysates $(50 \mu \mathrm{g})$ loaded onto tricine SDS-polyacrylamide $(7 \%$ or $10 \%)$ gel. After electrophoresis, proteins were transferred to polyvinylidene difluoride (PVDF) membranes (Immobilon-P; pore size, $0.45 \mu \mathrm{M}$; Millipore, Bedford, MA, USA) at $135 \mathrm{~mA}$ overnight at $4{ }^{\circ} \mathrm{C}$ in transfer buffer ( $50 \mathrm{mM}$ Tris- $\mathrm{HCl}$, $380 \mathrm{mM}$ glycine, $1 \%$ SDS, $20 \%$ methanol). The PVDF was incubated overnight at $4{ }^{\circ} \mathrm{C}$ with the anti-iNOS, anti-COX-2, or anti- $\beta$-actin antibodies. A horseradish peroxidase-conjugated secondary antibody was used for detection. Anti-iNOS (catalog no. 160862) and anti-COX-2 (catalog no. 160106) antibodies were purchased from Cayman Chemical Company (Ann Arbor, MI, USA). The $\beta$-actin antibody (catalog no. Actin sigma A5441) was purchased from Sigma-Aldrich (St. Louis, MO, USA). Immunoreactive bands were visualized by enhanced chemiluminescence (ECL kit; Millipore) and the BioChemi Imaging System and relative densitometric quantification was performed using LabWorks v6.2 (UVP, Upland, CA, USA). Bands for iNOS, COX-2, and $\beta$-actin antibodies were recognized at 135 , $\sim 72$, and $\sim 45 \mathrm{kDa}$, respectively. The experiment was repeated 3-4 times and data presented as the mean \pm standard error of the mean (SEM). For statistical analysis of immunoblot, the integrated optical density of the LPS group was set to $100 \%$, and $\beta$-actin was used to verify that equivalent amounts of protein were loaded in each lane. The data was analyzed by analysis of variance (ANOVA) with the Student-Newman-Keuls post hoc test for multiple comparisons. The difference was significant when $p$ was less than 0.05 .

\subsection{Cell Viability}

The RAW264.7 macrophage cell viability was determined after treatment with alamar blue (invitrogen, Carlsbad, CA, USA) [18], a tetrazolium dye that is reduced by living cells to fluorescent products. This assay is similar in principle to the cell viability assay using 3-(4,5-dimethyldiazol-2yl)-2,5-diphenyltetrazolium bromide and has been validated as an accurate measure of the survival of RAW264.7 macrophage cells.

Supplementary Materials: The Supplementary Materials are available online at http://www.mdpi.com/1660-3397/ 17/9/530/s1, Figure S1: ESIMS spectrum of compound 1, Figure S2: HRESIMS spectrum of compound 1, Figure S3: IR spectrum of compound 1, Figure S4: ${ }^{1} \mathrm{H}$ NMR spectrum (400 MHz) of compound 1 in $\mathrm{CDCl}_{3}$, Figure S5: ${ }^{13} \mathrm{C}$ NMR spectrum $(100 \mathrm{MHz})$ of compound $\mathbf{1}$ in $\mathrm{CDCl}_{3}$, Figure S6: DEPT spectrum of compound 1 in $\mathrm{CDCl}_{3}$, Figure S7: HSQC spectrum of compound 1 in $\mathrm{CDCl}_{3}$, Figure S8: HMBC spectrum of compound 1 in $\mathrm{CDCl}_{3}$, Figure S9: ${ }^{1} \mathrm{H}-{ }^{1} \mathrm{H}$ COSY spectrum of compound 1 in $\mathrm{CDCl}_{3}$, Figure S10: NOESY spectrum of compound $\mathbf{1}$ in $\mathrm{CDCl}_{3}$, Figure S11: ESIMS spectrum of compound 2, Figure S12: HRESIMS spectrum of compound 2, Figure S13: IR spectrum of compound 2, Figure S14: ${ }^{1} \mathrm{H}$ NMR spectrum $(400 \mathrm{MHz})$ of compound 2 in $\mathrm{CDCl}_{3}$, Figure S15: ${ }^{13} \mathrm{C}$ NMR spectrum $\left(100 \mathrm{MHz}\right.$ ) of compound 2 in $\mathrm{CDCl}_{3}$, Figure S16: DEPT spectrum of compound 2 in $\mathrm{CDCl}_{3}$, Figure S17: HSQC spectrum of compound 2 in $\mathrm{CDCl}_{3}$, Figure S18: HMBC spectrum of compound 2 in $\mathrm{CDCl}_{3}$, Figure S19: ${ }^{1} \mathrm{H}-{ }^{1} \mathrm{H}$ COSY spectrum of compound 2 in $\mathrm{CDCl}_{3}$, Figure S20: NOESY spectrum of compound 2 in $\mathrm{CDCl}_{3}$, Figure S21: The raw Western blotting data (pictures) of steroids 1-5.

Author Contributions: T.-H.H, T.-Y.W., and P.-J.S. designed the whole experiment and contributed to manuscript preparation. P.-C.C., S.-N.Y., F.-Y.L., T.-P.S., L.-Y.C., B.-R.P., C.-C.H., Y.-Y.C., and Z.-H.W. analyzed the data and performed data acquisition.

Funding: This research was supported by grants from the National Museum of Marine Biology and Aquarium; the National Dong Hwa University; and the Ministry of Science and Technology, Taiwan (Grant Nos: MOST 104-2320-B-291-001-MY3 and 107-2320-B-291-001-MY3) awarded to Ping-Jyun Sung.

Acknowledgments: We thank Nai-Cheng Lin in 2018 to support and afford us samples. The authors are grateful to the members of the analytical group of Test Center for data test, for measuring the spectroscopic data.

Conflicts of Interest: The authors declare no conflict of interest.

\section{References}

1. Carroll, A.R.; Copp, B.R.; Davis, R.A.; Keyzers, R.A.; Prinsep, M.R. Marine natural products. Nat. Prod. Rep. 2019, 36, 122-173. [CrossRef] [PubMed]

2. Duh, C.Y.; El-Gamal, A.A.H.; Song, P.Y.; Wang, S.K.; Dai, C.F. Steroids and sesquiterpenoids from the soft corals Dendronephthya gigantea and Lemnalia cervicorni. J. Nat. Prod. 2004, 67, 1650-1653. [CrossRef] [PubMed] 
3. Chao, C.H.; Wen, Z.H.; Chen, I.M.; Su, J.H.; Huang, H.C.; Chiang, M.Y.; Sheu, J.H. Anti-inflammatory steroids from the octocoral Dendronephthya griffini. Tetrahedron 2008, 64, 3554-3560. [CrossRef]

4. Chao, C.H.; Wen, Z.H.; Su, J.H.; Chen, I.M.; Huang, H.C.; Dai, C.F.; Sheu, J.H. Further study on antiinflammatory oxygenated steroids from the octocoral Dendronephthya griffini. Steroids 2008, 73, 1353-1358. [CrossRef] [PubMed]

5. Tomono, Y.; Hirota, H.; Imahara, Y.; Fusetani, N. Four new steroids from two octocorals. J. Nat. Prod. 1999, 62, 1538-1541. [CrossRef] [PubMed]

6. Ioannou, E.; Abdel-Razik, A.F.; Zervou, M.; Christofidis, D.; Alexi, X.; Vagias, C.; Alexis, M.N.; Roussis, V. $5 \alpha, 8 \alpha$-Epidioxysterols from the gorgonian Eunicella cavolini and the ascidian Trididemnum inarmatum: Isolation and evaluation of their antiproliferative activity. Steroids 2009, 74, 73-80. [CrossRef] [PubMed]

7. Gunatilaka, A.A.L.; Gopichand, Y.; Schmitz, F.J.; Djerassi, C. Minor and trace sterols in marine invertebrates. 26. Isolation and strucutre elucidation of nine new $5 \alpha, 8 \alpha$-epidioxy sterols from four marine organisms. J. Org. Chem. 1981, 46, 3860-3866. [CrossRef]

8. Huang, C.Y.; Chang, C.W.; Tseng, Y.J.; Lee, J.; Sung, P.J.; Su, J.H.; Hwang, T.L.; Dai, C.F.; Wang, H.C.; Sheu, J.H. Bioactive steroids from the Formosan soft coral Umbellulifera petasites. Mar. Drugs 2016, 14, 180. [CrossRef] [PubMed]

9. Huang, C.Y.; Liaw, C.C.; Chen, B.W.; Chen, P.C.; Su, J.H.; Sung, P.-J.; Dai, C.F.; Chiang, M.Y.; Sheu, J.H. Withanolide-based steroids from the cultured soft coral Sinularia brassica. J. Nat. Prod. 2013, 76, 1902-1908. [CrossRef] [PubMed]

10. Yan, X.H.; Liu, H.L.; Huang, H.; Li, X.B.; Guo, Y.W. Steroids with aromatic A-rings from the Hainan soft coral Dendronephthya studeri Ridley. J. Nat. Prod. 2011, 74, 175-180. [CrossRef] [PubMed]

11. Tomono, Y.; Hirota, H.; Fusetani, N. Isogosterones A-D, antifouling 13,17-secosteroids from an octocoral Dendronephthya sp. J. Org. Chem. 1999, 64, 2272-2275. [CrossRef]

12. Shin, K.; Chin, J.; Hahn, D.; Lee, J.; Hwang, H.; Won, D.H.; Ham, J.; Choi, H.; Kang, E.; Kim, H.; et al. Sterols from a soft coral, Dendronephthya gigantea as farnesoid X-activated receptor antagonists. Steroids 2012, 77, 355-359. [CrossRef] [PubMed]

13. Fernando, I.P.S.; Sanjeewa, K.K.S.; Kim, H.S.; Kim, S.Y.; Jeon, Y.J. Identification of sterols from the soft coral Dendronephthya gigantea and their anti-inflammatory potential. Environ. Toxicol. Pharm. 2017, 55, 37-43. [CrossRef] [PubMed]

14. Kim, E.A.; Ding, Y.; Yang, H.W.; Heo, S.J.; Lee, S.H. Soft coral Dendronephthya puetteri extract ameliorates inflammations by suppressing inflammatory mediators and oxidative stress in LPS-stimulated zebrafish. Int. J. Mol. Sci. 2018, 19, 2695. [CrossRef] [PubMed]

15. Fabricius, K.; Alderslade, P. Soft Corals and Sea Fans-A Comprehensive Guide to the Tropical Shallow-Water Genera of the Central-West Pacific, the Indian Ocean and the Red Sea, 1st ed.; Australian Institute of Marine Science: Townsville, Queensland, Australia, 2001; pp. 50-51; 112-115.

16. Hung, H.C.; Feng, C.W.; Lin, Y.Y.; Chen, C.H.; Tsui, K.H.; Chen, W.F.; Pan, C.Y.; Sheu, J.H.; Sung, C.S.; Wen, Z.H. Nucleophosmin modulates the alleviation of atopic dermatitis caused by the marine-derived compound dihydroaustrasulfone alcohol. Exp. Mol. Med. 2018, 50, e446. [CrossRef] [PubMed]

17. Jean, Y.H.; Chen, W.F.; Duh, C.Y.; Huang, S.Y.; Hsu, C.H.; Lin, C.S.; Sung, C.S.; Chen, I.M.; Wen, Z.H. Inducible nitric oxide synthase and cyclooxygenase-2 participate in anti-inflammatory and analgesic effects of the natural marine compound lemnalol from Formosan soft coral Lemnalia cervicorni. Eur. J. Pharmacol. 2008, 578, 323-331. [CrossRef] [PubMed]

18. Lin, Y.Y.; Lin, S.C.; Feng, C.W.; Chen, P.C.; Su, Y.D.; Li, C.M.; Yang, S.N.; Jean, Y.H.; Sung, P.J.; Duh, C.Y.; et al. Anti-inflammatory and analgesic effects of the marine-derived compound excavatolide B isolated from the culture-type Formosan gorgonian Briareum excavatum. Mar. Drugs 2015, 13, 2559-2579. [CrossRef] [PubMed]

(C) 2019 by the authors. Licensee MDPI, Basel, Switzerland. This article is an open access article distributed under the terms and conditions of the Creative Commons Attribution (CC BY) license (http://creativecommons.org/licenses/by/4.0/). 